\title{
Performance and emissions of a diesel engine using sunflower biodiesel with a renewable antioxidant additive from bio-oil
}

Cristina Dueso ${ }^{\mathrm{a}}$

Mariano Muñoz

Francisco Moreno ${ }^{\mathrm{b}}$

Jorge Arroyo ${ }^{\mathrm{b}}$

Noemí Gil-Lalaguna ${ }^{a}$

Ana Bautista ${ }^{c}$

Alberto Gonzalo,

José Luis Sánchez $z^{\mathrm{a}, \mathrm{c}, *}$

jlsance@unizar.es

aThermochemical Processes Group (GPT), Aragón Institute for Engineering Research (I3A), Universidad de Zaragoza, Spain

${ }^{\mathbf{b}}$ Department of Mechanical Engineering, EINA, Universidad de Zaragoza, Spain

'Department of Chemical and Environmental Engineering, EINA, Universidad de Zaragoza, María de Luna Street, 50018 Zaragoza, Spain

*Corresponding author at: Thermochemical Processes Group (GPT), Aragón Institute for Engineering Research (I3A), Universidad de Zaragoza, Spain.

Abstract

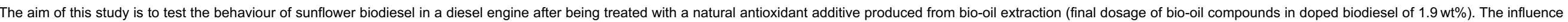

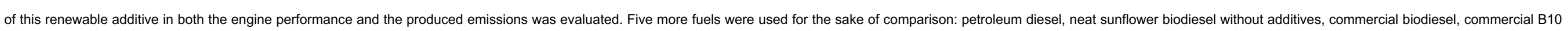

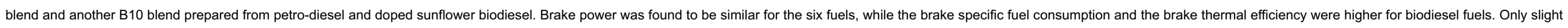

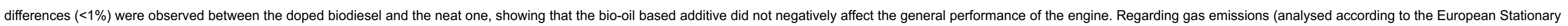

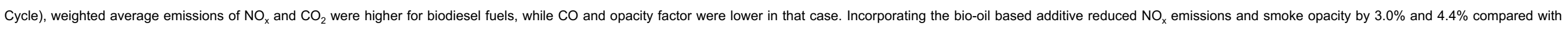
neat biodiesel, respectively, whilst $\mathrm{CO}$ and $\mathrm{HC}$ emissions increased by 0.7 and $14.3 \%$ respectively, values still remaining below those of diesel.

Keywords: Sunflower biodiesel; Bio-oil antioxidant additive; Diesel engine; Emissions; Engine performance

\section{Introduction}

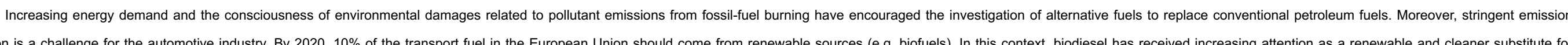

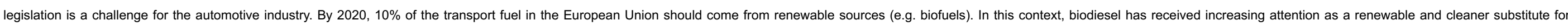
petroleum diesel. Final properties of biodiesel are similar to those of diesel, hence, neat biodiesel or blended with petroleum diesel can be used in conventional Cl engines without significant modifications [1].

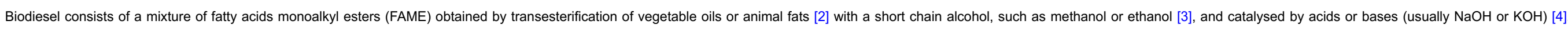

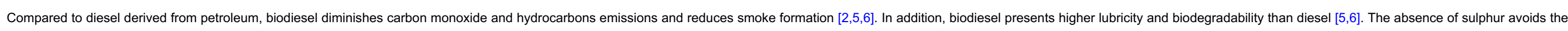




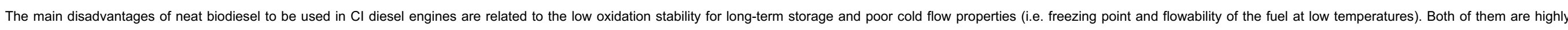

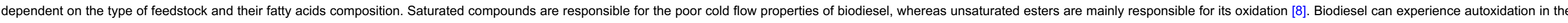

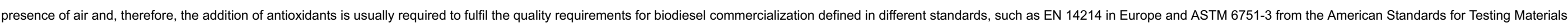

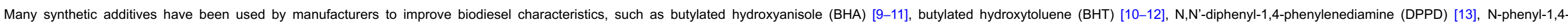

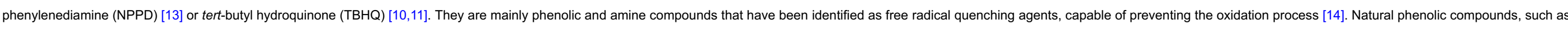

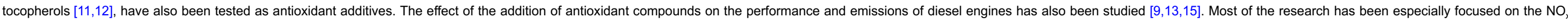

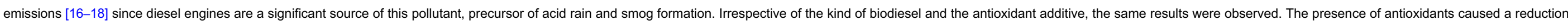
in $\mathrm{NO}_{x}$ emissions and smoke formation. In addition, $\mathrm{CO}$ and hydrocarbon concentrations in the exhaust gases rose. Power output generally increased whereas fuel consumption diminished with respect to the untreated biodiesel.

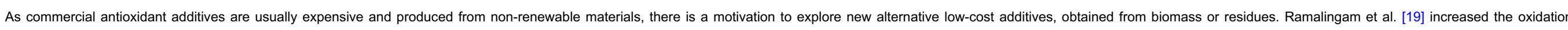

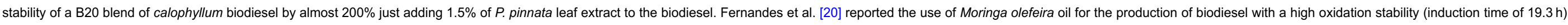

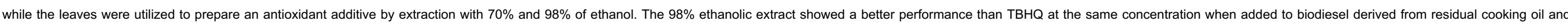
soybean oil.

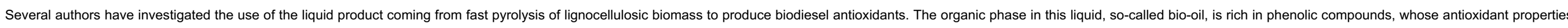



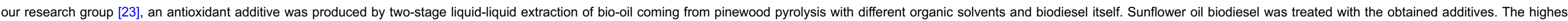

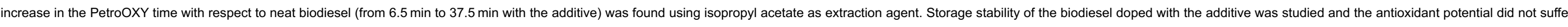
any deterioration over five months of storage.

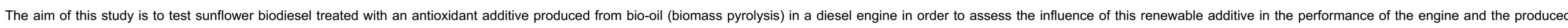

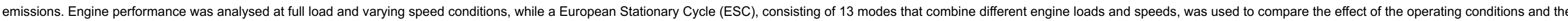

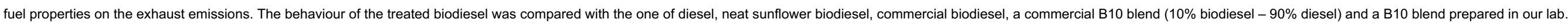

\section{Materials and methods}

\subsection{Fuels}

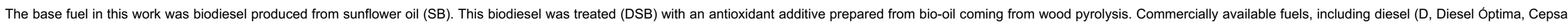

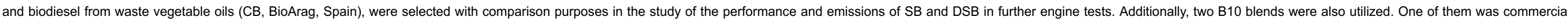
(CB10, Cooperativa Na Sa del Pilar, Novallas, Spain) and the second one was prepared by mixing D and DSB in the right proportions (SB10).

\subsubsection{Biodiesel production}

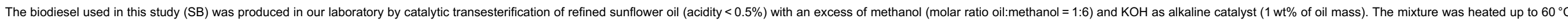

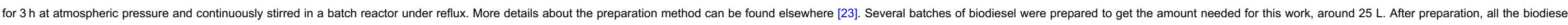
batches were mixed and kept at $-18^{\circ} \mathrm{C}$ until its utilization.

\subsubsection{Preparation of the antioxidant additive}

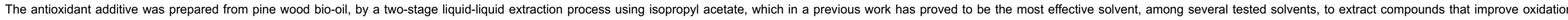

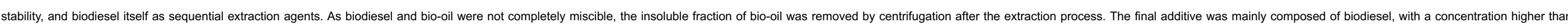




\subsubsection{Characterization}

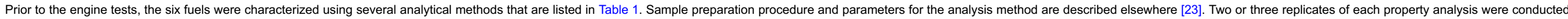

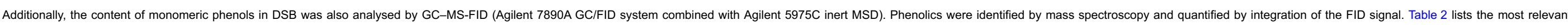

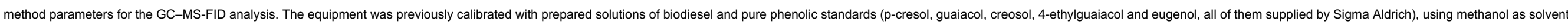

\section{Table 1 Analytical methods for the characterization of the fuels}

\begin{tabular}{|c|c|c|}
\hline Property & Equipment & Standard \\
\hline Density at $15^{\circ} \mathrm{C}$ & Densimeter Densito, 30 PX Mettler Toledo & - \\
\hline Kinematic viscosity at $40^{\circ} \mathrm{C}$ & Viscosimeter Cannon-Fenske, model 150 T845 & EN ISO 3104 \\
\hline $\mathrm{HHV}$ & Bomb calorimeter C2000 IKA & ISO 1928:2009 \\
\hline Oxidation stability & Fast oxidation instrument PetroOXY & ASTM D2274 \\
\hline CFPP & Automated analyser FPP 5GS model V22101 & EN 16329 \\
\hline Water content & Coulometer Mettler Toledo C20 Compact KF & EN ISO 12937 \\
\hline Elemental analysis & Elemental analyser LECO CHN 628 and LECO $628 \mathrm{~S}$ & - \\
\hline FAME content & GC-FID Agilent 6890 GC System & EN 14103 \\
\hline
\end{tabular}

Table 2 Method parameters for GC-MS-FID analysis of monomeric phenols in DSB.

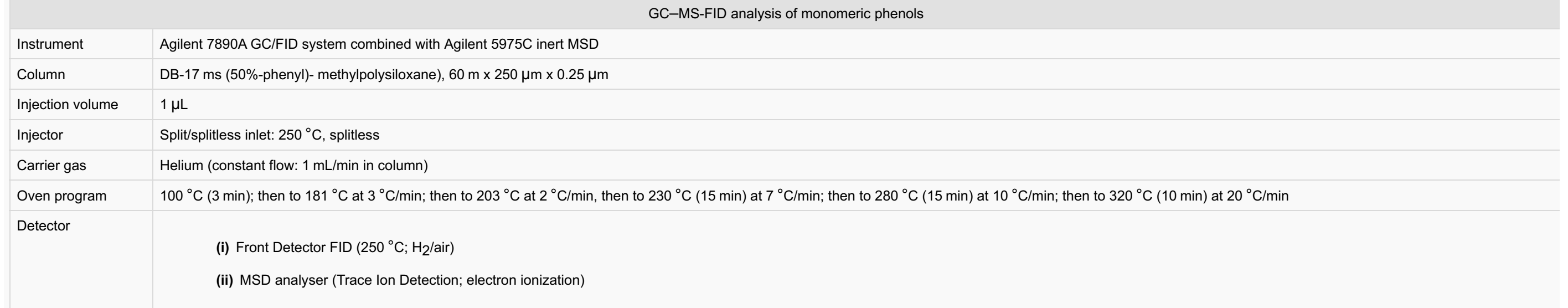

\subsection{Diesel engine test bench}

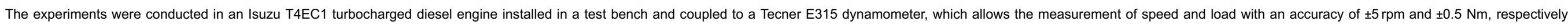

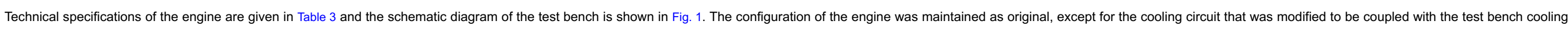
circuit. To avoid any thermal stress and preserve the mechanical system, the maximum absolute boost pressure was limited to 1.5 bar. 


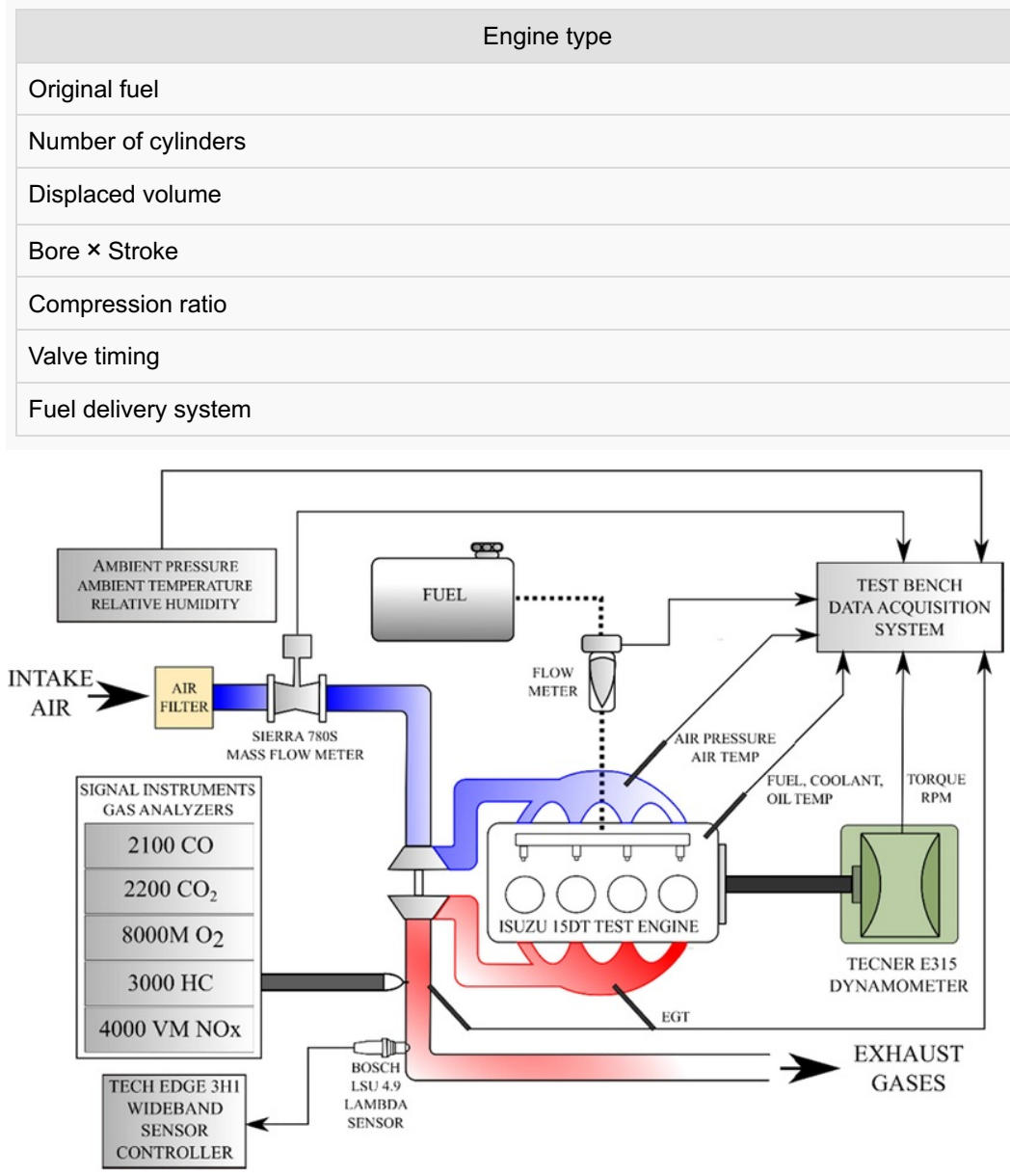

Fig. 1 Schematic diagram of the engine test bench.

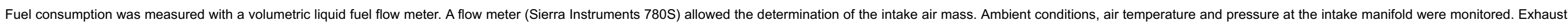



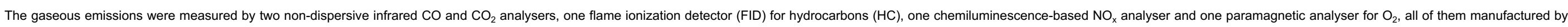
Signal Instruments. The values of opacity, expressed as $\mathrm{mg}$ of soot per $\mathrm{m}^{3}$, were provided by a Bosch smoke-meter for diesel engines (filter type, Model RFT $100 \mathrm{FD}$ ). More details about this installation can be found in [24].

\subsubsection{Experimental procedure}

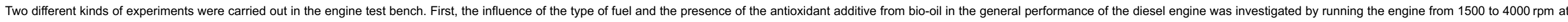
full load with the six fuels. The evolution of the brake power (BP), brake specific fuel consumption (BSFC) and brake thermal efficiency (BTE) was analysed.

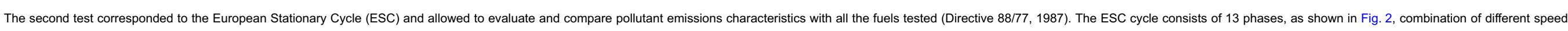

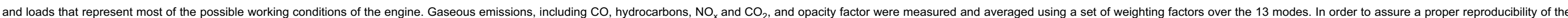






\section{Results and discussion}

\subsection{Fuel characterization}

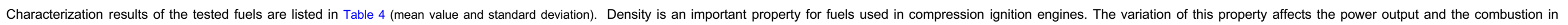

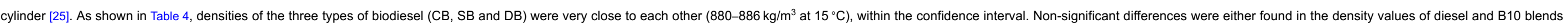

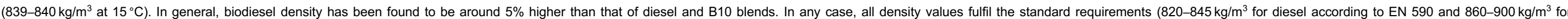
biodiesel according to EN 14214). Similar values are reported by other authors using sunflower biodiesel. Thus, values of 882.2, 885, and $883.6 \mathrm{~kg} / \mathrm{m}^{3}$ were obtained by Saydut el al. [26], Saba et al. [27] and Santos et al. [28], respectively.

Table 4 Physico-chemical properties of the tested fuels.

\begin{tabular}{|c|c|c|c|c|c|c|c|}
\hline \multicolumn{2}{|c|}{ Fuel properties } & D & $\mathrm{CB}$ & SB & DSB & CB10 & SB10 \\
\hline Density at $15^{\circ} \mathrm{C}$ & $\mathrm{kg} / \mathrm{m}^{3}$ & $840 \pm 2$ & $880 \pm 3$ & $884 \pm 4$ & $886 \pm 4$ & $840 \pm 5$ & $839 \pm 4$ \\
\hline Viscosity at $40^{\circ} \mathrm{C}$ & $\mathrm{mm}^{2} / \mathrm{s}$ & $2.80 \pm 0.01$ & $4.58 \pm 0.01$ & $4.47 \pm 0.05$ & $4.30 \pm 0.06$ & $2.90 \pm 0.01$ & $2.79 \pm 0.04$ \\
\hline $\mathrm{HHV}$ & $\mathrm{MJ} / \mathrm{kg}$ & $45.62 \pm 0.09$ & $39.8 \pm 0.1$ & $39.83 \pm 0.01$ & $39.63 \pm 0.03$ & $45.09 \pm 0.03$ & $45.21 \pm 0.02$ \\
\hline Oxidation stability & $\min$ & $94.2 \pm 0.7$ & $40.6 \pm 0.1$ & $13.8 \pm 0.3$ & $37.61 \pm 0.01$ & $43 \pm 2$ & $106.9 \pm 0.7$ \\
\hline CFPP & ${ }^{\circ} \mathrm{C}$ & $-16.1 \pm 1$ & $0.4 \pm 1$ & $-5.1 \pm 1$ & $-2.9 \pm 1$ & $-15.6 \pm 1$ & $-16.1 \pm 1$ \\
\hline Water content & $\mathrm{ppm}$ & $75 \pm 27$ & $189 \pm 54$ & $579 \pm 4$ & $587 \pm 3$ & $73 \pm 19$ & $115 \pm 24$ \\
\hline Carbon & $\%$ & $86.6 \pm 0.1$ & $77.66 \pm 0.03$ & $78.04 \pm 0.06$ & $77.56 \pm 0.07$ & $86.11 \pm 0.07$ & $86.3 \pm 0.2$ \\
\hline Hydrogen & $\%$ & $13.2 \pm 0.1$ & $12.25 \pm 0.08$ & $12.07 \pm 0.04$ & $12.05 \pm 0.05$ & $13.42 \pm 0.00$ & $13.4 \pm 0.1$ \\
\hline Nitrogen & $\mathrm{ppm}$ & $1800 \pm 400$ & $2400 \pm 100$ & $1600 \pm 200$ & $1570 \pm 80$ & $1900 \pm 200$ & $1680 \pm 50$ \\
\hline Oxygen ${ }^{*}$ & $\%$ & 0.0 & 9.8 & 9.7 & 10.2 & 0.25 & 0.05 \\
\hline Sulphur & ppm & $324 \pm 16$ & $269 \pm 8$ & $279 \pm 24$ & $257 \pm 9$ & $316 \pm 3$ & $281 \pm 19$ \\
\hline FAME content & $w t \%$ & - & $93.4 \pm 0.2$ & $98.6 \pm 0.2$ & $96.7 \pm 0.1$ & - & - \\
\hline
\end{tabular}

*Calculated by difference. 


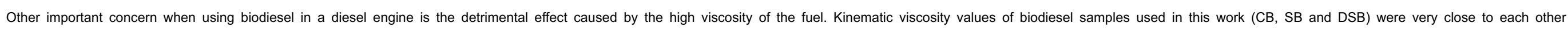

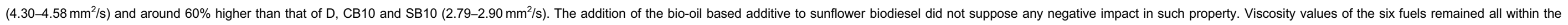

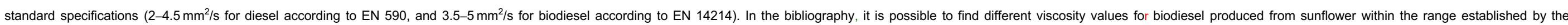

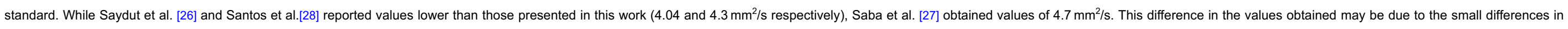
the composition of the raw material and to the amount and composition of the impurities present in the final product.

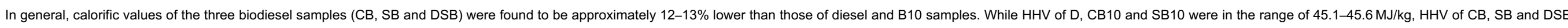
hardly varied between 39.6 and $39.8 \mathrm{MJ} / \mathrm{kg}$. The addition of the bio-oil based additive to biodiesel only led to a very slight reduction in the fuel calorific value $(0.5 \%$ lower)

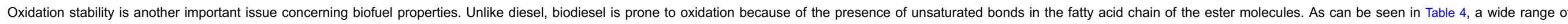

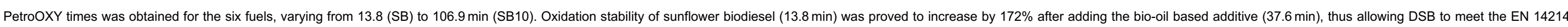

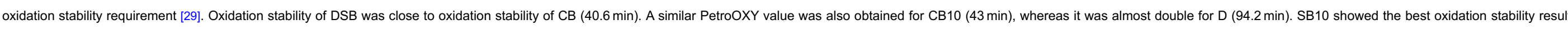
(106.9 min).

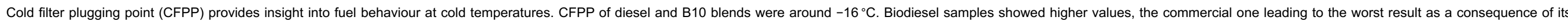

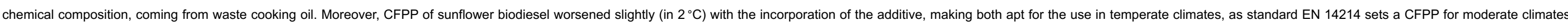
ranging from $+5^{\circ} \mathrm{C}$ to $-20^{\circ} \mathrm{C}$

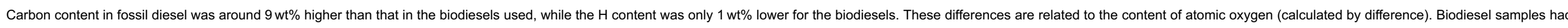
about $10 \mathrm{wt} \%$ of oxygen, while oxygen in diesel and B10 blends is negligible. Regarding the presence of nitrogen and sulphur, the highest percentage of $\mathrm{N}$ was found in commercial biodiesel, while diesel showed the highest $\mathrm{S}$ content.

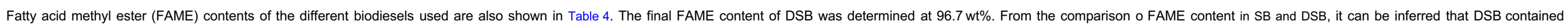
$1.9 \mathrm{wt} \%$ of bio-oil compounds.

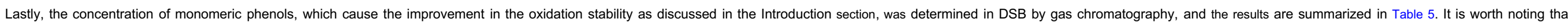

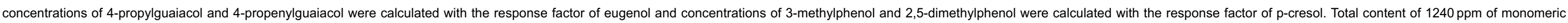
phenols was detected in DSB, creosol being the most abundant phenolic compound identified by this technique.

Table 5 Concentration of monomeric phenols in DSB.

\begin{tabular}{|c|c|c|}
\hline Compound & Retention time (min) & Concentration (ppm) \\
\hline 3-methylphenol & 12.57 & 31 \\
\hline guaiacol (2-methoxyphenol) & 13.83 & 285 \\
\hline 2,5-dimethylphenol & 15.18 & 63 \\
\hline creosol (4-methylguaiacol) & 17.42 & 463 \\
\hline 4-ethylguaiacol & 20.60 & 123 \\
\hline 4-proylguaiacol & 23.86 & 27 \\
\hline eugenol (4-(2-propenyl)-guaiacol) & 24.17 & 132 \\
\hline 4-propenylguaiacol & 26.71 & 61 \\
\hline (E)-4-propenylguaiacol & 28.61 & 57 \\
\hline Vanillin & 29.27 & n.q. \\
\hline acetoguaiacol & 32.66 & n.q. \\
\hline
\end{tabular}


n.q.: not quantified.

\subsection{Full load tests}

\subsubsection{Brake power (BP)}

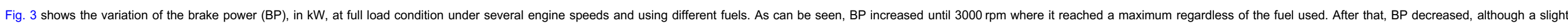

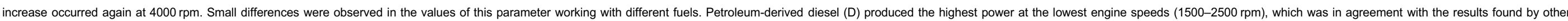


biodiesel (SB), so it did not cause a significant negative effect on the brake power.

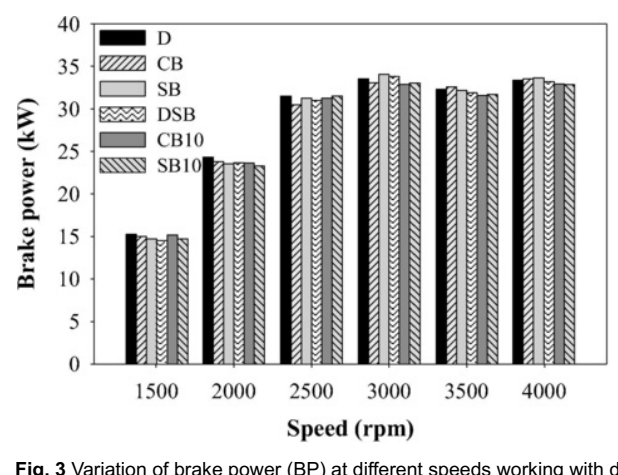

\subsubsection{Brake specific fuel consumption (BSFC)}

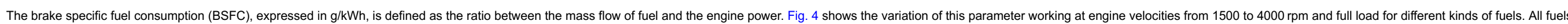
followed the same trend, with the lowest values at $1500-2500 \mathrm{rpm}$ and a further increase up to $4000 \mathrm{rpm}$.

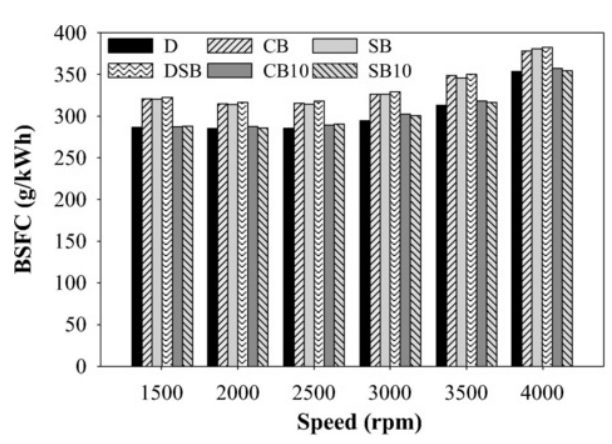

Fig. 4 Variation of brake specific fuel consumption (BSFC) at different speeds working with different fuels.

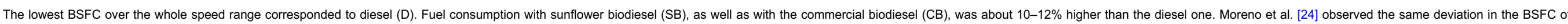

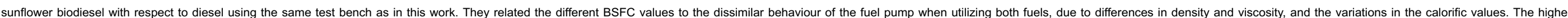



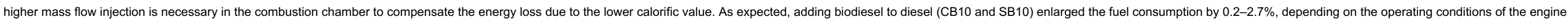




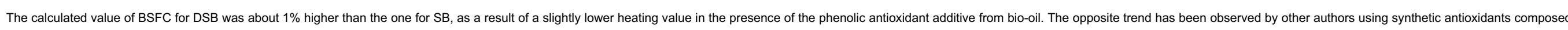

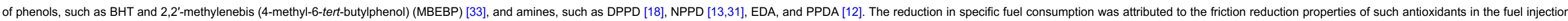

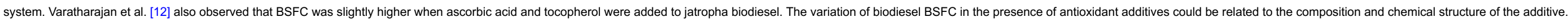

\subsubsection{Brake thermal efficiency (BTE)}



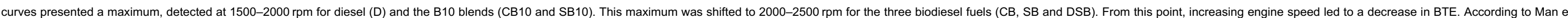
al. [34], higher engine speeds cause a rise in the specific fuel consumption and, consequently, a decrease in BTE.

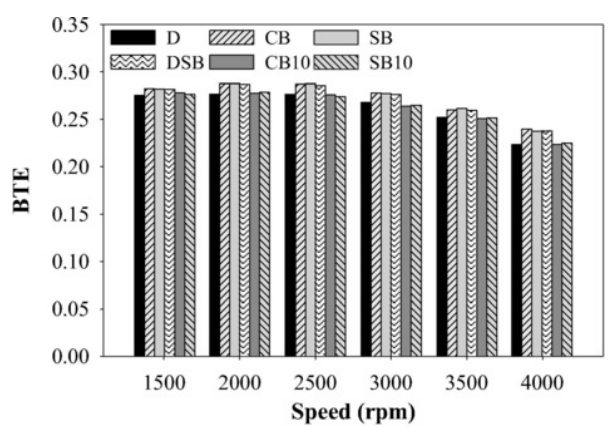

Fig. 5 Variation of brake thermal efficiency (BTE) at different speeds working with different fuels.



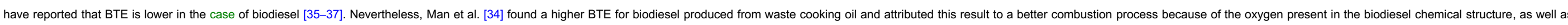

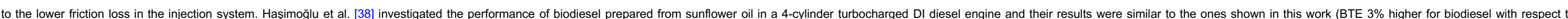
diesel).

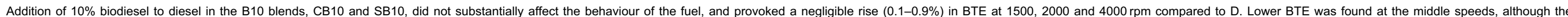
difference was also very small $(0.1-1.2 \%)$.

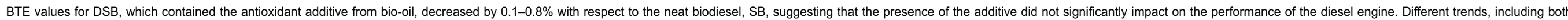

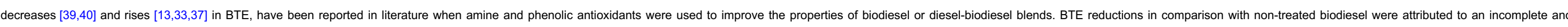
improper combustion resulting from the antioxidant addition

\subsection{Esc test cycle}

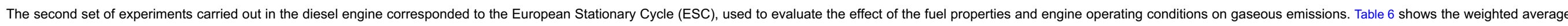
results for $\mathrm{NO}_{x}, \mathrm{CO}, \mathrm{CO}_{2}, \mathrm{HC}$ and opacity and for the six fuels tested.

Table 6 Weighted average emissions in ESC cycle test.

Fue

$\mathrm{NO}$

$g / k W \cdot h$ $g / k W \cdot h$ $g / k W \cdot h$
Opacity

$\mathrm{mg} / \mathrm{m}^{3}$
$\mathrm{CO}_{2}$

$g / k W \cdot h$
2.62

2.85
4.16

2.91
0.64

0.58
4.94

1.69
187

1214 


\begin{tabular}{|l|l|l|l|l|l|l|l|l|}
\hline SB & 2.96 & 2.92 & 0.35 & 1.59 & 0.40 & 1207 \\
\hline DSB & 2.87 & 2.94 & 0.39 & 1.52 \\
\hline CB10 & 2.75 & 3.73 & 0.43 & 1129 \\
\hline SB10 & 2.81 & 3.97 & 1187 \\
\hline
\end{tabular}

\subsubsection{NO emissions}

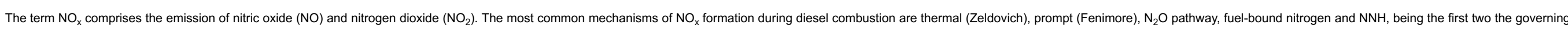

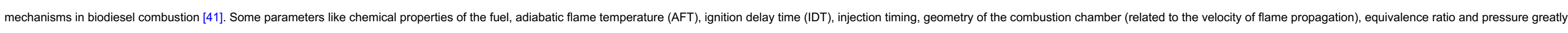
affect $\mathrm{NO}_{\mathrm{x}}$ emissions [10].

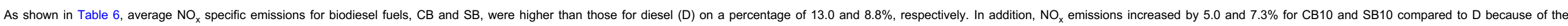

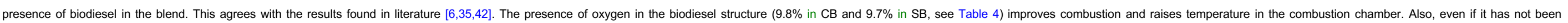

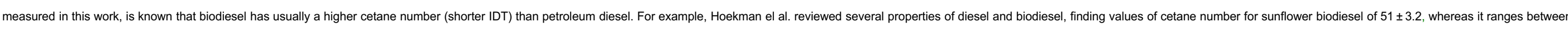
40 and 45 for petroleum diesel [43]. Both effects would lead to $\mathrm{NO}_{x}$ formation increases.

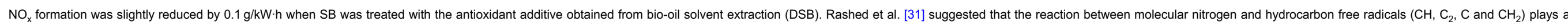
role on prompt $\mathrm{NO}_{x}$ emission during the combustion of biodiesel. Antioxidants can act as radical quenching agents and, therefore, diminish $\mathrm{NO}_{x}$ formation.

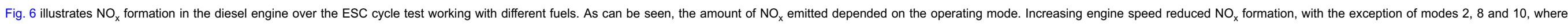


independently of the fuel used and the engine speed. An increase in the engine load led to more fuel injected. This caused a rise in the temperature and promoted $\mathrm{NO}_{x}$ formation [44].



Fig. $6 \mathrm{NO}_{x}$ emissions at different engine modes working with different fuels.

\subsubsection{Carbon monoxide emissions}



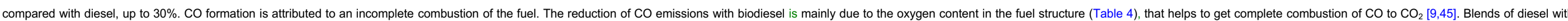
biodiesel (CB10 and SB10) reduced CO emissions by 10.3 and $4.6 \%$, respectively, compared to fossil diesel.

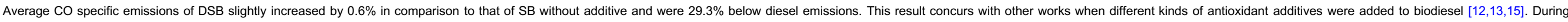
oxidation, the formation of several radicals takes place, peroxyl $\left(\mathrm{HO}_{2}\right)$ and hydrogen peroxide $\left(\mathrm{H}_{2} \mathrm{O}_{2}\right)$ among them. They are further converted into hydroxyl radicals $(\mathrm{OH})$, involved in the conversion of $\mathrm{CO}$ into $\mathrm{CO}$, by 


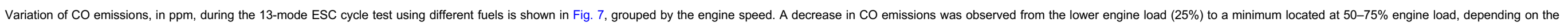

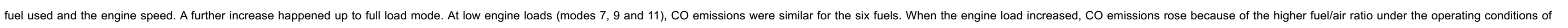
modes 2, 8 and 10, at full load [34].

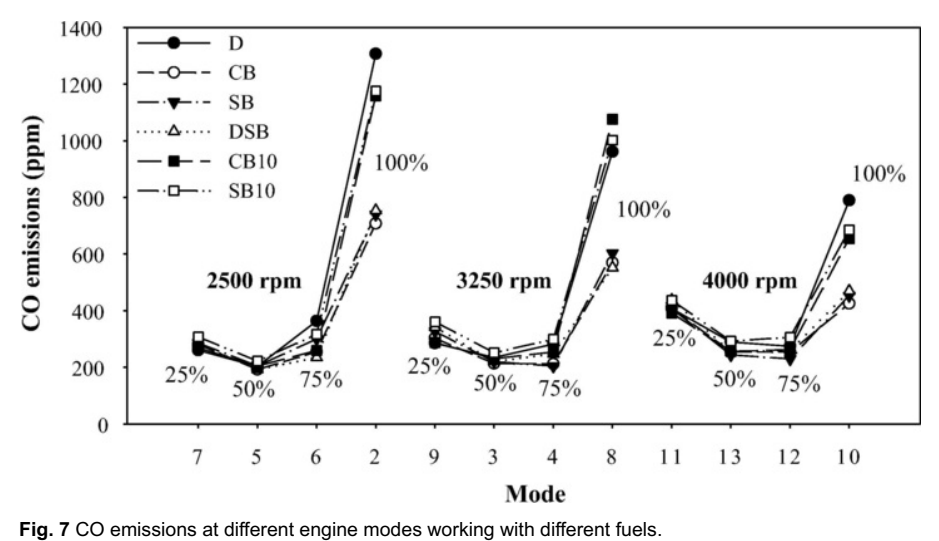

Fig. 7 CO emissions at different engine modes working with different fuels.

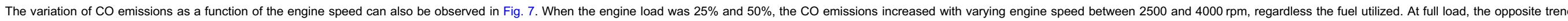

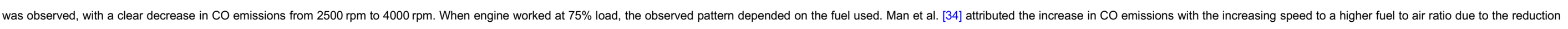
in volumetric efficiency and increase in fuel consumption.

\subsection{3 $\mathrm{CO}_{2}$ emissions}

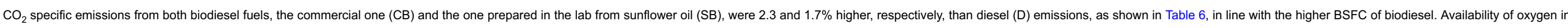


instead of diesel. When the antioxidant additive from bio-oil was added to the sunflower biodiesel, $\mathrm{CO}_{2}$ emissions augmented $1.2 \%$ with respect to the neat biodiesel.

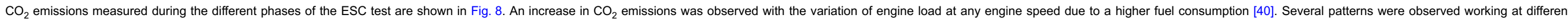


Moreover, $\mathrm{CO}_{2}$ emissions presented a maximum at $3250 \mathrm{rpm}$ at full load.

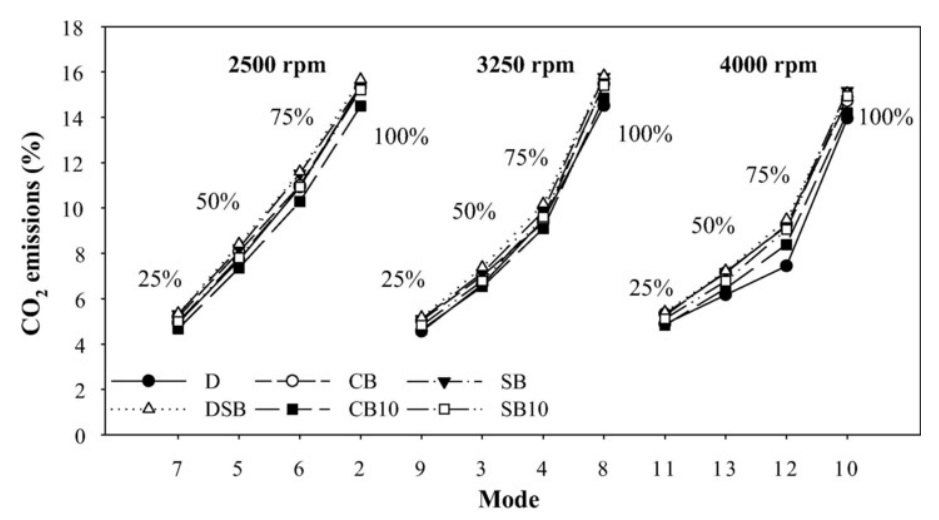




\subsubsection{HC emissions}

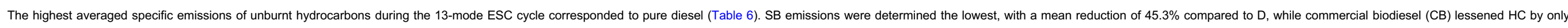

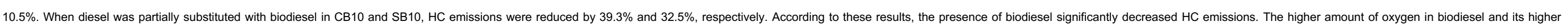

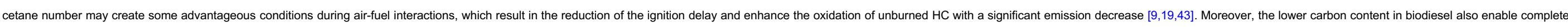
combustion to a greater extent [46].

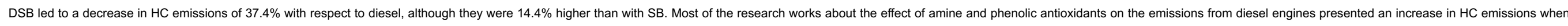


gases [12,40].




pattern. Emissions increased with engine speed at the lower engine load (25\%), while the opposite trend was observed at the highest load (100\%). At middle engine loads, a maximum at $3250 \mathrm{rpm}$ was found in most of the cases.

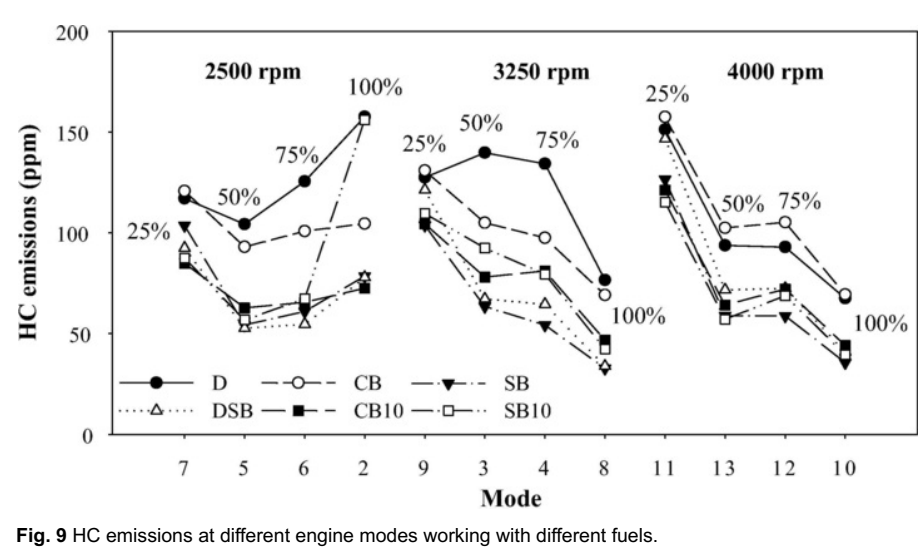

\subsubsection{Opacity}

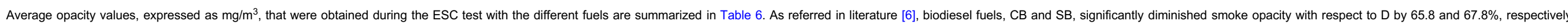

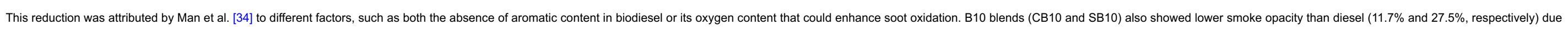

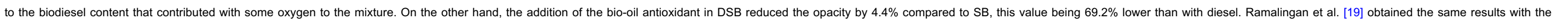

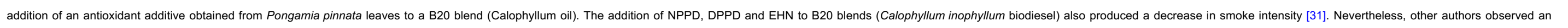
increase in the smoke production using antioxidant additives such as DPPD [47], BHA and BHT [17], but still below the diesel level. They attributed this rise to the reduction of oxygen availability and the increase in C $\mathrm{C}$ bonds and aromatic content.

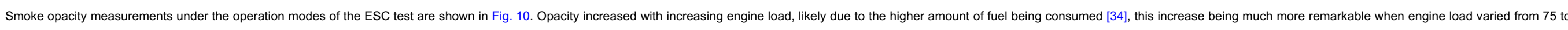

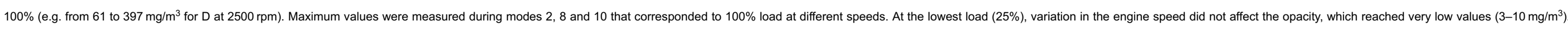
From $50 \%$ engine load to full load, opacity decreased with increasing engine speed. 


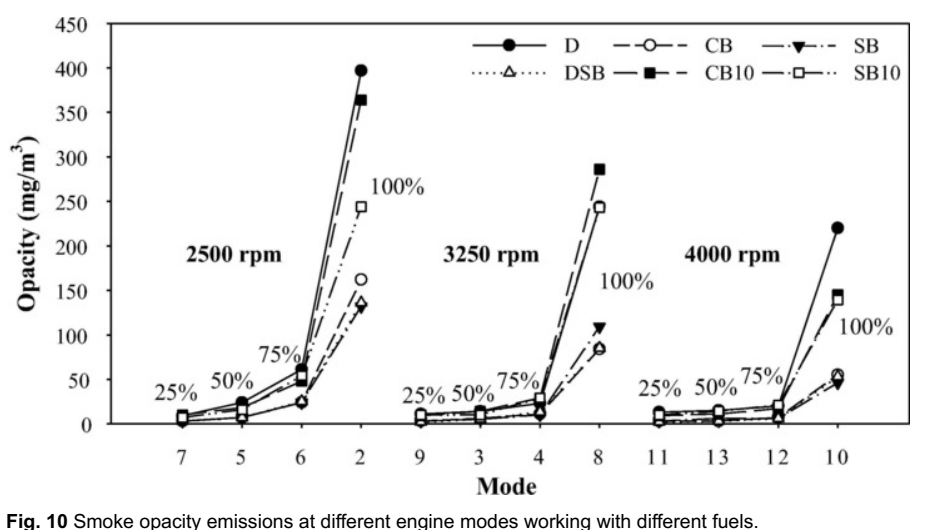

\section{Conclusions}

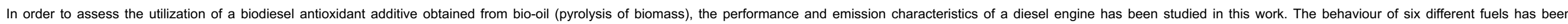
compared. The obtained results suggest the following conclusions:

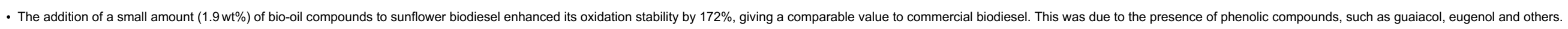

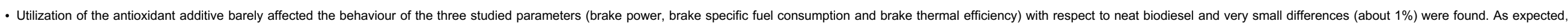

BP was higher when using diesel instead of biodiesel. On the contrary, BSFC and BTE were increased in the presence of biodiesel.

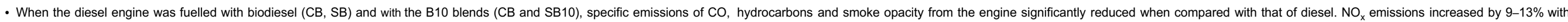
biodiesel and 5-7.3\% with B10 blends. Meanwhile, $\mathrm{CO}_{2}$ augmented in average $2 \%$ with biodiesel and decreased with the commercial B10.

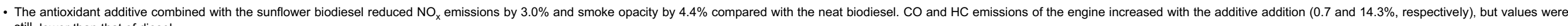
still lower than that of diesel.

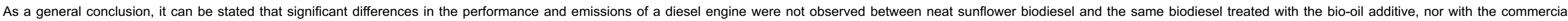
biodiesel. Hence, bio-oil could be a suitable source of renewable and low-cost antioxidant additives for biodiesel as a replacement for synthetic and expensive compounds currently used.

\section{Acknowledgements}

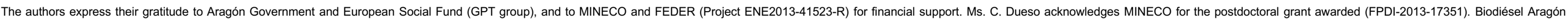
S.L. is acknowledged for kindly supplying the commercial biodiesel.

\section{References}

[1] F. Neto da Silva, A. Salgado Prata and J. Rocha Teixeira, Technical feasibility assessment of oleic sunflower methyl ester utilisation in Diesel bus engines, Energy Convers Manage 44 (18), $2003,2857-2878$.

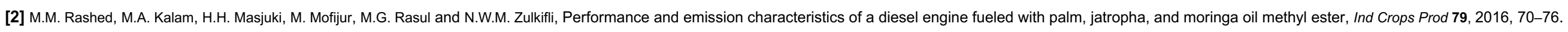

[3] M. Garcia, A. Gonzalo, J.L. Sanchez, J. Arauzo and C. Simoes, Methanolysis and ethanolysis of animal fats: a comparative study of the influence of alcohols, Chem Ind Chem Eng Q 17 (1), 2011, 91-97.

[4] E. Lotero, Y. Liu, D.E. Lopez, K. Suwannakarn, D.A. Bruce and J.G. Goodwin, Synthesis of biodiesel via acid catalysis, Ind Eng Chem Res 44 (14), 2005, 5353-5363.

[5] A. Murugesan, C. Umarani, R. Subramanian and N. Nedunchezhian, Bio-diesel as an alternative fuel for diesel engines-A review, Renew Sustain Energy Rev 13 (3), $2009,653-662$. 
[6] J. Xue, T.E. Grift and A.C. Hansen, Effect of biodiesel on engine performances and emissions, Renew Sustain Energy Rev 15 (2), 2011, 1098-1116.

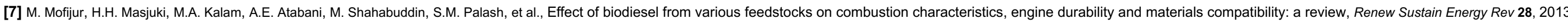
$441-455$.

[8] M. Garcia-Perez, T.T. Adams, J.W. Goodrum, K.C. Das and D.P. Geller, DSC studies to evaluate the impact of bio-oil on cold flow properties and oxidation stability of bio-diesel, Bioresour Technol 101 (15), $2010,6219-6224$.

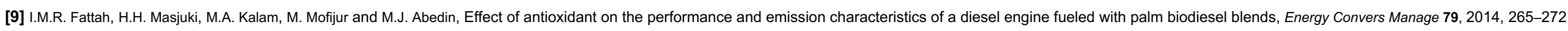

[10] E. Ileri and G. Koçar, Experimental investigation of the effect of antioxidant additives on NOx emissions of a diesel engine using biodiesel, Fuel 125, $2014,44-49$.

[11] K. Ryu, The characteristics of performance and exhaust emissions of a diesel engine using a biodiesel with antioxidants, Bioresour Technol 101 (Suppl 1), 2010, S78-S82.

[12] K. Varatharajan, M. Cheralathan and R. Velraj, Mitigation of NOx emissions from a jatropha biodiesel fuelled DI diesel engine using antioxidant additives, Fue/ 90 (8), $2011,2721-2725$.

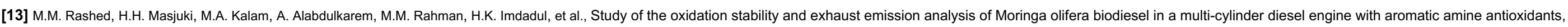
Renewable Energy 94, 2016, 294-303.

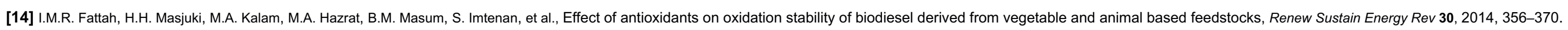

[15] E. Ileri and G. Koçar, Effects of antioxidant additives on engine performance and exhaust emissions of a diesel engine fueled with canola oil methyl ester-diesel blend, Energy Convers Manage 76, $2013,145-154$.

[16] G. Balaji and M. Cheralathan, Study of antioxidant effect on oxidation stability and emissions in a methyl ester of neem oil fuelled DI diesel engine, J Energy Inst 87 (3), $2014,188-195$.



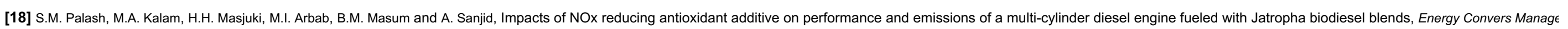
$77,2014,577-585$.

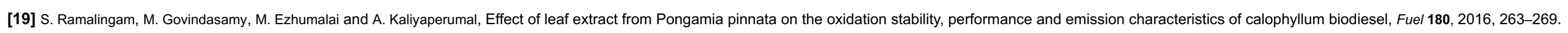

[20] D.M. Fernandes, R.M.F. Sousa, A. de Oliveira, S.A.L. Morais, E.M. Richter and R.A.A. Muñoz, Moringa oleifera: a potential source for production of biodiesel and antioxidant additives, Fuel 146, 2015, 75-80.

[21] L. Botella, M. Sierra, F. Bimbela, G. Gea, J.L. Sánchez and A. Gonzalo, Enhancement of biodiesel oxidation stability using additives obtained from sewage sludge fast-pyrolysis liquids, Energy Fuels 30, 2015 , 302-310.

[22] M. Garcia-Perez, J. Shen, X.S. Wang and C.-Z. Li, Production and fuel properties of fast pyrolysis oil/bio-diesel blends, Fuel Process Technol 91 (3), $2010,296-305$.

[23] M. García, L. Botella, N. Gil-Lalaguna, J. Arauzo, A. Gonzalo and J.L. Sánchez, Antioxidants for biodiesel: additives prepared from extracted fractions of bio-oil, Fuel Process Technol 156, $2017,407-414$.

[24] F. Moreno, M. Muñoz and J. Morea-Roy, Sunflower methyl ester as a fuel for automobile diesel engines, Trans ASAE 42 (5), 1999, 1181-1185.

[25] V.K. Shahir, C.P. Jawahar and P.R. Suresh, Comparative study of diesel and biodiesel on Cl engine with emphasis to emissions-A review, Renew Sustain Energy Rev 45, $2015,686-697$.

[26] A. Saydut, S. Erdogan, A.B. Kafadar, C. Kaya, F. Aydin and C. Hamamci, Process optimization for production of biodiesel from hazelnut oil, sunflower oil and their hybrid feedstock, Fuel 183, $2016,512-517$.

[27] T. Saba, J. Estephane, B. El Khoury, M. El Khoury, M. Khazma, H. El Zakhem, et al., Biodiesel production from refined sunflower vegetable oil over KOH/ZSM5 catalysts, Renewable Energy 90, 2016, 301-306.

[28] A.G.D. Santos, V.P.S. Caldeira, M.F. Farias, A.S. Araújo, L.D. Souza and A.K. Barros, Characterization and kinetic study of sunflower oil and biodiesel, J Therm Anal Calorim 106 (3), 2011, 747-751.


$2014,2$.




$78-84$.


273-284.

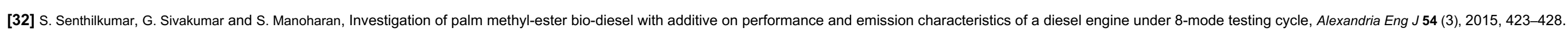


Manage 106, 2015, 849-858.

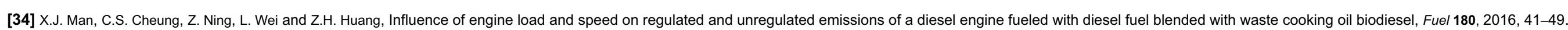

[35] K. Vijayaraj and A.P. Sathiyagnanam, Experimental investigation of a diesel engine with methyl ester of mango seed oil and diesel blends, Alexandria Eng J 55 (1), $2016,215-221$.

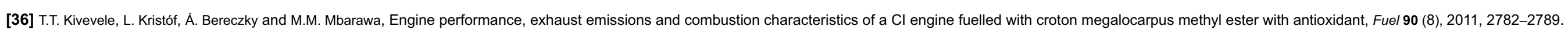

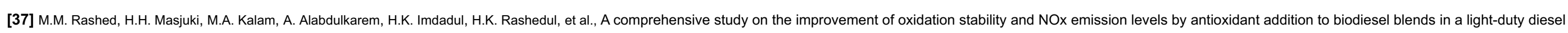
engine, RSC Adv 6 (27), 2016, 22436-22446.

[38] C. Haşimoğlu, M. Ciniviz, I. Özsert, Y. lçingür, A. Parlak and M. Sahir Salman, Performance characteristics of a low heat rejection diesel engine operating with biodiesel, Renew Energy 33 (7), 2008, 1709-1715.



[40] G. Balaji and M. Cheralathan, Experimental investigation of antioxidant effect on oxidation stability and emissions in a methyl ester of neem oil fueled DI diesel engine, Renewable Energy 74, $2015,910-916$.

[41] S.M. Palash, M.A. Kalam, H.H. Masjuki, B.M. Masum, I.M.R. Fattah and M. Mofijur, Impacts of biodiesel combustion on NOx emissions and their reduction approaches, Renew Sustain Energy Rev 23, 2013, 473-490.

[42] D. Singh, K.A. Subramanian and S.K. Singal, Emissions and fuel consumption characteristics of a heavy duty diesel engine fueled with hydroprocessed renewable diesel and biodiesel, Appl Energy 155, 2015, 440-446.

[43] S.K. Hoekman, A. Broch, C. Robbins, E. Ceniceros and M. Natarajan, Review of biodiesel composition, properties, and specifications, Renew Sustain Energy Rev 16 (1), 2012 , 143-169.



[45] A. Uyumaz, Combustion, performance and emission characteristics of a DI diesel engine fueled with mustard oil biodiesel fuel blends at different engine loads, Fuel 212, $2018,256-267$.

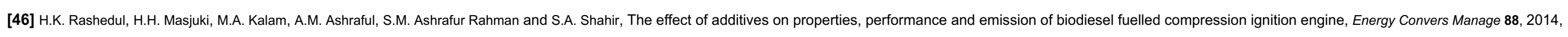
348-364.

[47] K. Varatharajan and M. Cheralathan, Effect of aromatic amine antioxidants on NOx emissions from a soybean biodiesel powered DI diesel engine, Fuel Process Technol 106, $2013,526-532$.

Highlights

- Biodiesel oxidation stability can be improved with a bio-oil derived additive.

- Performance and emissions of a diesel engine are not significantly modified by this additive.

- Biodiesel, with and without additive, improves most of the emissions measured. 